\title{
PEMAKNAAN PERAN MATA KULIAH AKUNTANSI SYARIAH DI PERGURUAN TINGGI DALAM PEMILIHAN KARIR DI LEMBAGA JASA KEUANGAN SYARIAH
}

\author{
Anna Sutrisna $S$ \\ (Jurusan Akuntansi Politeknik Negeri Ujung Pandang) \\ Saiful Muchlis \\ (Jurusan Akuntansi FEB UIN Alauddin Makassar)
}

\begin{abstract}
This study aims to discover the role of Accounting Sharia courses in college against the interests of students accounting for a career in the Organization of Islamic Financial Services. This study is a qualitative research and processed using interpretive paradigm in the level of theory and practice. The informants as many as five people who are accounting students who have passed the course Accounting Sharia in Politeknik Negeri Ujung Pandang. The results of this study showed that purport accounting subjects of sharia in college in the selection of a career in financial services institution of sharia are students there who were trapped in material values that are infused with the scent of mechanistic and unisex students who expect professionalism tiered in a career in LJKS and neglect the suitability of theory and practice in operational performance in LJKS. Those that are still stuck in the value circle material in the sense of an income. In addition there are also prioritizing the suitability of theory and practice. But there are still caught in a cycle value of the materials in an income and interpret the meaning of the latter is to ignore the suitability of theory and practice in operational performance in LJKS and still trapped inside the circle in the value of the material interpret the meaning of an income. Overall concluded that accounting sharia courses in college for students accounting role in the selection of a career in LJKS.
\end{abstract}

Keywords: Professionalism, Compliance Value Theory and Practice

\section{Pendahuluan}

Akuntan publik dibutuhkan guna Kurikulum pendidikan yang ada di Indonesia telah mengalami banyak perubahan kearah perubahan yang lebih baik. Khususnya kurikulum untuk perguruan tinggi telah disusun dengan mempertimbangkan kebutuhan industri, dalam hal kebutuhan tenaga kerja yang bermutu dan berkualitas. Untuk merespon kebutuhan industi tersebut, pemerintah telah menyusun Kerangka Kualifikasi Nasional Indonesia (KKNI), yang diatur dalam Peraturan Menteri Pendidikan dan Kebudayaan Republik Indonesia Nomor 73 Tahun 2013, tentang Penerapan Kerangka Kualifikasi Nasional Indonesia yang mengatur diantaranya adalah mewajibkan setiap program studi pada perguruan tinggi menyusun dokumen kurikulum, termasuk bahan kajian atau mata kuliah yang memang dibutuhkan, agar mahasiswa lulusannya memiliki kompetensi dan berkualitas, sehingga mendapat pengakuan dibidangnya, dan dapat terserap di berbagai sektor bisnis maupun pemerintahan. KKNI merupakan perwujudan mutu dan jati diri bangsa Indonesia, terkait dengan sistem pendidikan nasional dan pelatihan yang dimiliki Bangsa Indonesia, sehingga lulusan perguruan tinggi dapat menghadapi tantangan dan memperoleh kesempatan untuk unggul dalam sebuah sistem Masyarakat Ekonomi Asean (MEA).

Riset Akuntansi dan Keuangan Indonesia, 1(1), 2016
Setiap perguruan tinggi wajib memperhatikan kebutuhan pasar kerja agar lulusan nya dapat terserap di pasar kerja tersebut. Tidak terkecuali perguruan tinggi yang menyelenggarakan pendidikan akuntansi baik itu pendidikan akademik (S1, S2 dan S3) serta Pendidikan Vokasi Akuntansi dan Profesi Akuntansi. Bagi penyelenggara pendidikan akuntansi harus mampu menyediakan bahan kajian atau mata kuliah yang mengikuti perkembangan dunia kerja dan dunia bisnis tanpa melupakan etika dan sikap yang terpuji dalam kurikulum yang disusun oleh perguruan tinggi salah satunya adalah mata kuliah Akuntansi Syariah. Kurikulum yang ada di perguruan tinggi berupa mata kuliah Akuntansi Syariah menyiapkan mahasiswa nya untuk terjun dan berkarir pada Lembaga Jasa Keuangan Syariah (LJKS) sebab perkembangan ekonomi dan bisnis Islam atau yang lebih dikenal bisnis berbasis syariah semakin luas bahkan pelaku bisnis mengakui bahwa bisnis berbasis syariah mampu bertahan dalam kondisi ekonomi sulit sekalipun melihat sejarah pada tahun 1997 Indonesia mengalami Krisis Moneter yang amat dahsyat yang merontokkan perekonomian yang berbasis konvensional namun perekonomian berbasis syariah mampu bertahan hingga saat ini dan bahkan LJKS semakin merambah keberbagai sektor keuangan diantaranya Perbankan Syariah, Asuransi Syariah, Pegadaian Syariah dan masih banyak lagi lembaga jasa keuangan yang berbasis syariah selain 
itu Lembaga Jasa Keuangan Syariah Nirlaba juga turut berkembang diantaranya Organisasi Pengelola Zakat baik Badan Amil Zakat maupun Lembaga Amil Zakat dan Badan Wakaf. Dengan semakin berkembangnya LJKS tentunya membutuhkan tenaga kerja yang telah siap kerja dan memahami prinsip dan sistem syariah. Untuk itu peranan mata kuliah Akuntansi Syariah memang sangat penting dalam menyiapkan lulusan mahasiswa akuntansi agar mengenal dan memahami prinsip dan sistem berbasis syariah.

Lulusan mahasiswa akuntansi tidak hanya terbatas pada karir menjadi seorang akuntan, baik akuntan publik hingga menjadi akuntan pemerintah, bahkan dapat bekerja pada lembaga jasa keuangan syariah namun lulusan akuntansi dapat memilih banyak pilihan karir. Dalam memilih karir yang akan dijalaninya, mahasiswa akuntansi memiliki berbagai macam pertimbangan untuk memilih karir apa yang akan dijalaninya. Faktor-faktor yang mempengaruhi terdiri dari penghargaan finansial, pelatihan profesional, nilai-nilai sosial, lingkungan kerja, pertimbangan pasar kerja dan personalitas (Rahayu, 2003). Karir merupakan suatu akumulasi dan pengetahuan yang tertanam pada skill, expertise, dan jaringan hubungan kerja yang lebih luas (Bird,1994 dalam Sadeli dan Ishak, 2014). Namun sebaliknya, Greenberg dan Baron,2000 dalam Sadeli dan Ishak, 2014 menyatakan bahwa karir tersebut meliputi urutan pengalaman pekerjaan seseorang selama jangka waktu tertentu. Pilihan karir mahasiswa dipengaruhi oleh stereotype yang mereka bentuk tentang berbagai macam karir (Holland,1995 dalam Friendland, 1996 dalam Rahayu, 2003)

Namun apakah setiap mahasiswa jurusan akuntansi termotivasi untuk berkarir pada LJKS selain berkarir menjadi akuntan dan profesi lainnya setelah lulus mata kuliah Akuntansi Syariah? Ataukah hanya memanfaatkan kesempatan atas sebuah lowongan pekerjaan tanpa memperhatikan ilmu yang telah diperoleh dibangku kuliah. Inilah yang merupakan dasar peneliti untuk menemukan peranan mata kuliah Akuntansi Syariah terhadap mahasiswa jurusan akuntansi memilih berkarir pada Lembaga Jasa Keuangan Syariah setelah lulus kuliah. Penelitian ini berbeda dengan penelitianpenelitian sebelumnya sebab penelitian terdahulu lebih banyak mencari alasan mahasiswa memilih berkarir sebagai akuntan maupun selain akuntan dan penelitian ini ingin melihat peranan kurikulum berupa mata kuliah Akuntansi Syariah yang disediakan oleh perguruan tinggi terhadap minat mahasiswa untuk berkarir pada salah satu Lembaga Jasa Keuangan Syariah.

\section{Kajian Pustaka dan Pengembangan Hipotesis $\square$}

\section{Konsep Lembaga Keuangan Syariah}

Lembaga keuangan syariah adalah lembaga keuangan yang menjalankan kegiatannya dengan berlandaskan prinsip syariah Islam. Lembaga Keuangan Syariah terdiri dari Bank dan non Bank (Asuransi, Pegadaian, Reksa Dana, Pasar Modal, BPRS, dan BMT). Ciri-ciri sebuah Lembaga Keuangan Syariah dapat dilihat dari hal-hal sebagai berikut:

1. Dalam menerima titipan dan investasi, Lembaga Keuangan Syariah harus sesuai dengan fatwa Dewan Pengawas Syariah

2. Hubungan antara investor (penyimpan dana), pengguna dana, dan Lembaga Keuangan Syariah sebagai intermediary institution, berdasarkan kemitraan, bukan hubungan debitur-kreditur

3. Bisnis Lembaga Keuangan Syariah bukan hanya berdasarkan profit orianted, tetapi juga falah orianted, yakni kemakmuran di dunia dan kebahagiaan di akhirat

4. Konsep yang digunakan dalam transaksi Lembaga Syariah berdasarkan prinsip kemitraan bagi hasil, jual beli atau sewa menyewa guna transaksi komersial, dan pinjam-meminjam (qardh/ kredit) guna transaksi sosial Lembaga Keuangan Syariah hanya melakukan investasi yang halal dan tidak menimbulkan kemudharatan serta tidak merugikan syiar Islam

\section{Mata Kuliah Akuntansi Syariah Berperan dalam Pemilihan Karir}

Berdasarkan hasil penelitian yang dilakukan oleh Sawarjuwono dan Mustika (2014) menyatakan bahwa kebutuhan akan lulusan akuntansi yang bekerja di bidang syariah semakin mendesak seiring dengan perkembangan sektor bisnis syariah sehingga program pendidikan akuntansi yang ada menyiapkan lulusan yang siap terserap dan siap pakai di sektor bisnis syariah. Salah satu bentuk dukungan pemerintah adalah Kerangka Kualifikasi Nasional Indonesia (KKNI) yang diatur dalam Peraturan Menteri Pendidikan dan Kebudayaan Republik Indonesia Nomor 73 Tahun 2013 tentang Penerapan Kerangka Kualifikasi Nasional Indonesia yang mengatur diantaranya adalah mewajibkan setiap program studi pada perguruan tinggi menyusun dokumen kurikulum termasuk bahan kajian atau mata kuliah yang memang dibutuhkan agar mahasiswa lulusannya memiliki kompetensi dan berkualitas sehingga mendapat pengakuan dibidangnya yang dapat terserap di berbagai sektor bisnis maupun pemerintahan.

Sampai saat ini hampir seluruh perguruan tinggi di Indonesia yang memiliki program studi Akuntansi menyelenggarakan kurikukulum sesuai dengan aturan pemerintah. Ditinjau dari definisi kurikulum dalam Kepmendiknas No. 232/U/2000 
adalah sebagai berikut:

"Kurikulum pendidikan tinggi adalah seperangkat rencana dan pengaturan mengenai isi maupun bahan kajian dan pelajaran serta cara penyampaian dan penilaian yang digunakan sebagai pedoman penyelenggaraan kegiatan belajar-mengajar di perguruan tinggi."

Dengan demikian kurikulum adalah sebuah program yang disusun dan dilaksanakan untuk mencapai suatu tujuan pendidikan. Jadi kurikulum bisa diartikan sebuah program yang berupa rincian mata kuliah, silabus, rancangan pembelajaran, serta sistem evaluasi keberhasilan proses belajar mengajar. Dengan demikian kurikulum harus dapat memenuhi perkembangan kebutuhan para penggunanya (Brand, 2012) dalam Sawarjuwono (2014). Lulusan sarjana akuntan harus memiliki kompetensi khusus. Salah satu mata kuliah yang ada dalam kurikulum pendidikan akuntansi adalah mata kuliah Akuntansi Syariah yang biasanya di ampuh pada semester 4 atau semester 5. Pada mata kuliah tersebut diperkenalkan mengenai akuntansi syariah serta berbagai lembaga keuangan bisnis yang berbasis syariah selain itu dalam mata kuliah tersebut juga membahas produk-produk perbankan mulai mudharabah hingga ijarah. Berdasarkan hal tersebut menjadi sebuah perhatian khusus bagi peneliti untuk menguji pengaruh mata kuliah Akuntansi terhadap minat mahasiswa akuntansi dalam memilih berkarir pada Lembaga Jasa Keuangan Syariah.

Sampai saat ini peneliti belum menemukan penelitian mengenai peranan mata kuliah dalam pemilihan karir khususnya pada Lembaga Jasa Keuangan Syariah. Namun beberapa penelitian terdahulu telah banyak menguji faktor-faktor yang mempengaruhi pemilihan berkarir diantaranya sebagai berikut:

\section{Nilai Intrisik Pekerjaan}

Nilai intrinsik berhubungan dengan kepuasan yang dirasakan oleh individu ketika melakukan pekerjaan sehingga terdapat hubungan langsung antara pekerjaan dan penghargaan. Nilai intrinsik pekerjaan memiliki hubungan dengan kepuasan yang dierima oleh individu saat atau sesudah ia melakukan pekerjaan (job content). Menurut Gibson, Ivancevich dan Donnely (1997), faktor intrinsik meliputi, pekerjaan yang menantang secara intelektual, berada dalam lingkungan dinamis, mendukung kreativitas, dan memberikan kebebasan atau otonomi. Penelitian yang dilakukan oleh Paotolilo dan Estes (1982) dalam Sadeli dan Ishak (2014) menyimpulkan bahwa kepuasan kerja merupakan faktor yang tidak penting bagi akuntan dibanding bagi pengacara, insinyur, atau ilmuwan di dalam memilih profesi. Nilai intrinsik pekerjaan berhubungan dengan kepuasan yang diperoleh atau suatu pekerjaan yang dilakukan.

\section{Penghargaan finansial/ Gaji}

Menurut penelitian Stolle (1976) dalam Sadeli dan Ishak (2014) yang termasuk dalam penghargaan finansial/ gaji adalah penghargaan finansial/ gaji awal,dana pensiun, dan potensi kenaikan penghargaan finansial/gaji. Mahasiswa yang memilih profesi akuntan pemerintah dan akuntan pendidik lebih mengharapkan dan pensiun dibandingkan dengan mahasiswa yang memilih profesi akuntan perusahaan dan akuntan publik. Rahayu et.al (2003).

\section{Lingkungan Kerja}

Widyastuti (2004) menunjukkan bahwa lingkungan kerja,dipertimbangkan dalam pemilihan profesi mahasiswa terutama pada sifat pekerjaan rutin dan pekerjaan cepat diselesaikan. Rahayu (2003) menunjukkan bahwa mahasiswa yang memilih profesi akuntan pendidik menganggap pekerjaan yang dijalani lebih rutin dibandingkan karir. Mahasiswa yang memilih profesi sebagai akuntan pemerintah menganggap pekerjaannya rutinitas lebih tinggi dibanding akuntan perusahaan. Mahasiswa yang memilih profesi sebagai akuntan publik menganggap jenis pekerjaannya tidak rutin, akan tetapi pekerjaannya mempuanyai banyak tantangan dan tidak dapat dengan cepat terselesaikan.

\section{Pelatihan Profesional}

Beberapa elemen dalam pelatihan profesional antara lain: pelatihan sebelum bekerja, mengikuti pelatihan di luar lembaga, mengikuti pelatihan rutin lembaga, dan variasi pengalaman kerja. Menurut Widyastuti (2004) menunjukkan bahwa pelatihan profesional, tidak dipertimbangkan dalam pemilihan profesi mahasiswa, kecuali faktor pengalaman kerja yang bervariasi dipertimbangkan oleh mahasiswa yang memilih profsi akuntan publik dan akuntan pemerintah. Mahasiswa beranggapan pelatihan profesional ini perlu dilakukan oleh semua profesi akuntansi. Mahasiswa yang memilih profesi akuntan pendidik menganggap tidak perlu pelatihan kerja sebelum memulai pekerjaan. Mahasiswa yang memilih profesi akuntan publik menganggap pelatihan kerja tidak terlalu diperlukan dalam menjalankan karirnya (Rahayu,2003).

\section{Nilai-Nilai Sosial}

Widyastuti (2004) mengungkapkan bahwa nilai-nilai sosial, dipertimbangkan oleh mahasiswa akuntansi dalam memilih profesi yang meliputi: kesempatan berinteraksi, kepuasan pribadi, kesempatan untuk menjalankan hobi, dan perhatian perilaku individu. Pandangan mahasiswa akuntansi terhadap hal-hal tersebut juga berbeda-beda sesuai dengan jenis pekerjaan dalam profesi yang dipilih. Sedangkan nilai-nilai sosial tidak dipertimbangan dalam pemilihan profesi adalah prestise pekerjaan dan kerjasama dengan ahli bidang lain. 


\section{Pertimbangan Pasar Kerja}

Hasil penelitian Setiyani (2005) dalam Sadeli dan Ishak (2014) menjelaskan bahwa pertimbangan pasar kerja merupakan faktor yang mempengaruhi mahasiswa untuk memilih berprofesi sebagai akuntan publik. Akan tetapi pertimbangan pasar kerja bukan merupakan faktor yang mempengaruhi mahasiswa yang memilih berprofesi pada non akunan publik. Andri (2004) mengungkapkan bahwa tidak ada perbedaan pandangan pertimbangan pasar kerja dalam memilih profesi akuntan publik, akuntan perusahaan, akuntan pemerintah dan akuntan pendidik.

Hasil penelitan Rahayu (2003) menunjukkan bahwa mahasiswa yang memilih profesi akuntan pemerintah dan akuntan pendidik menganggap keamanan kerja dan profesinya lebih aman dibandingkan dengan perofesi akuntan lainnya. Mahasiswa yang memilih profesi akuntan yang memilih akuntan publik menganggap pekerjaannya kurang aman tetapi masih lebih aman dibandingkan profesi akuntan perusahaan. Berbeda dengan penelitian Jadongan (2004), mengungkapkan bahwa pertimbangan pasar kerja tidak dipertimbangkan dalam pemilihan profesi akuntan publik maupun profesi non akuntan publik.

\section{Metode Penelitian}

\section{Situs dan Fokus Penelitian}

Situs penelitian ini dilakukan di Kampus

Politeknik Negeri Ujung Pandang (PNUP), yang beralamat di Jalan Perintis Kemerdekaan No. 10 Makassar. Fokus penelitian yaitu Peranan Mata Kuliah Akuntansi Syariah di Perguruan Tinggi terhadap Minat Mahasiswa Akuntansi untuk berkarir di Lembaga Jasa Keuangan Syariah. Subyek penelitian ini terdiri dari lima (5) orang mahasiswa jurusan akuntansi yang telah lulus mata kuliah akuntansi syariah. Kelima orang mahasiswa tersebut, merupakan informan dalam penelitian ini.

\section{Paradigma Penelitian Kualitatif}

Penelitian ini berupaya untuk mengungkap makna peranan mata kuliah akuntansi syariah yang ada pada perguruan tinggi dengan minat mahasiswa dalam memilih karir di salah satu Lembaga Jasa Keuangan Syariah (LJKS). Penelitian ini merupakan jenis penelitian kualitatif dengan menggunakan paradigma interpretive, pendekatan fenomenologi. Menurut Moleong (2005), penelitian kualitatif adalah penelitian yang bermaksud untuk memahami fenomena tentang apa yang dialami oleh subjek penelitian misalnya perilaku, persepsi, motivasi, tindakan, dan lain-lain secara holistik dengan cara deskripsi dalam bentuk kata-kata dan bahasa pada suatu konteks khusus yang alamiah dan dengan memanfaatkan berbagai metode yang alamiah.

Metode interpretive mengacu pada pengertian bahwa peneliti akan mencoba memahami dan memaknai setiap penjelasan dari informan, serta suasana dan sifat (nature of) pendidikan, bisnis dan perubahan perkembangan yang terjadi, serta proses pendidikan yang sedang berjalan. Dengan metode tersebut akan dapat menghasilkan teori yang akan bermuara pada kebutuhan pembahasan kurikulum akuntansi syariah pada perguruan tinggi yang ada di Indonesia.

Pemilihan informan dalam penelitian ini adalah menggunakan teknik purposive sampling. Informan penelitian ini adalah kelompok mahasiswa dari sebuah Perguruan Tinggi Negeri, yatu di Politeknik Negeri Ujung Pandang pada jurusan Akuntansi. Kriteria informan yang ditetapkan adalah mahasiswa jurusan akuntansi yang telah lulus mata kuliah Akuntansi Syariah yang kemungkinan akan berbeda tingkatan semesternya akan tetapi substansi keilmuan akuntansi syariah telah diperoleh.

\section{Pengumpulan Data}

Teknik pengumpulan data dilakukan dengan cara indepth interview. Hal ini dilakukan oleh peneliti karena agar dapat mempertemukan pendapat dari beberapa orang informan mengenai peranan mata kuliah Akuntansi Syariah terhadap minat dalam berkarir pada Lembaga Jasa Keuangan Syariah. Kemudian data berupa dokumentasi diantaranya rekaman, foto dari pelaksanaan wawancara, akan dilakukan interpretasi khususnya dengan menerapkan thematic analysis. Selain itu proses interpretasi dilakukan secara content analysis yaitu dengan cara mempelajari inti penjelasan pendapat yang diberikan oleh setiap informan.

\section{Analisis Data}

Adapun teknik analisis yang digunakan dalam penelitian ini mengacu pada metode analisis kualitatif yang disampaikan oleh Miles \& Huberman, yaitu analisis data interaktif (Nuradilla,dkk.2014). Analisis ini terdiri dari tiga alur kegiatan yang terjadi secara bersamaan, yaitu : reduksi data, penyajian data, dan penarikan kesimpulan/verifikasi.

\section{Reduksi Data}

Reduksi data adalah proses pemilihan, pemusatan perhatian, pada penyederhanaan pengabstrakan, dan transformasi data kasar yang muncul dari catatan-catatan tertulis dilapangan. Proses ini terus berlangsung terus menerus selama penelitian berlangsung, bahkan sebelum data benarbenar terkumpul sebagaimana kerangka konseptual, permasalahan studi, dan pendekatan penelitian yang dipilih oleh peneliti.

\section{Penyajian Data}

Penyajian data adalah kegiatan ketika sekumpulan informasi disusun, sehingga memberi kemungkinan akan adanya penarikan kesimpulan dan pengambilan tindakan.

3. Verifikasi

Dalam proses ini, peneliti mulai melakukan interpretasi yaitu memberikan makna pada data atau 
informasi yang telah disaji dan berjalan terus bagai sebuah siklus. Karena peneliti melakukan penelitian dengan menggunakan pandangan fenomenologi, maka alur analisis yang digunakan oleh peneliti mengacu pada analisis data yang disampaikan oleh Amadeo Giorgi dalam Nurardilla (2014), yaitu :

a. Peneliti membaca keseluruhan ungkapan yang disampaikan oleh informan dengan tujuan untuk mendapatkan arti umum dari informasi tersebut. Ketika membaca keseluruhan ungkapan yang disampaikan oleh informan, peneliti juga berpegang pada konteks penelitian yang dilakukan peneliti agar peneliti dapat menangkap ungkapan yang dimaksud oleh informan.

b. Peneliti akan membaca keseluruhan teks kembali dengan tujuan khusus, yaitu untuk memilih atau membedakan (discriminating) unit makna (meaning unit) dan dengan perhatian penuh pada fenomena yang sedang diteliti oleh peneliti.

c. Peneliti melihat dan membaca seluruh unit makna sambil memperhatikan apakah unit makna tersebut benar-benar memiliki keterkaitan dengan topik yang dibahas dan diteliti oleh peneliti.

d. Peneliti membuat sintesa dari semua unit makna yang ditransformasi dalam satu statemen yang sesuai dengan pengalaman informan.

\section{Hasil dan Pembahasan}

\section{Informan sebagai Sumber Informasi}

Pada prinsipnya muatan kurikulum yang ada di perguruan tinggi telah disesuaikan dengan KKNI khususnya perguruan tinggi yang menyelenggarakan program studi maupun jurusan akuntansi. Namun belum sepenuhnya setiap mata kuliah yang ada di kurikulum berpengaruh pada minat mahasiswa berkarir setelah lulus kuliah termasuk kurikulum mata kuliah Akuntansi Syariah. Informan dalam penelitian ini, yaitu mahasiswa jurusan akuntansi yang telah lulus mata kuliah Akuntansi Syariah, yang terdiri dari lima (5) orang informan, yaitu: Yulia, Muhammad Fadhillah, Halimah, Sri Wahyuni dan Yuliana Jasmin. Mereka yang menginginkan pendalaman secara spesifik atas materi yang ada pada mata kuliah Akuntansi Syariah maupun mata kuliah Akuntansi Perbankan syariah adalah mahasiswa yang berasal dari lulusan siswa SMK jurusan Akuntansi, sebab mereka menganggap bahwa materi yang telah diperoleh dibangku kuliah, pernah mereka pelajari di bangku sekolah. Berikut argumentasi dari mahasiswa tersebut:

Yulia mengatakan" materi kuliah akuntansi perbankan syariah itu pernah saya dapat waktu sekolah dulu di SMK walaupun mata pelajaran Perbankan, tetapi guru kami memperkenalkan dan menjelaskan tentang perbankan syariah, sehingga ketika hendak mengikuti mata kuliah akuntansi syariah, saya menjadi bosan karena tidak ada tambahan ilmu tentang akuntansi syariah itu seperti apa sebenarnya. Saya mengetahui sampai sekarang perbedaan utama akuntansi syariah, dan akuntansi konvensional. Hanya saja dari sistem bagi hasilnya jika hal itu yang ditanyakan kepada saya, saya belum mendapatkan perbedaan lainnya, kecuali materinya perlu untuk dijelaskan secara lebih spesifik dan kalau perlu, diperbanyak dengan contoh-contoh atas materi tersebut".

Hal yang senada juga di ungkapkan oleh Muhammad Fadhillah, yaitu, "mata kuliah akuntansi syariah bukan hal yang baru buat saya, sebab waktu sekolah dahulu, ada pelajaran tentang perbankan yang didalamnya membahas tentang materi perbankan syariah. Pembahasan yang saya peroleh di mata kuliah akuntansi syariah, sama persis dengan yang saya peroleh ketika masih sekolah di SMK dahulu. Mungkin untuk lebih baiknya, pendalaman materinya lebih dirancang secara sistematis karena pasti akuntansi syariah dan akuntansi konvensional itu ada perberdaannya yang mendasar"

Halimah menyatakan bahwa "kalau saya barasal dari lulusan SMA, jadi saya baru mengenal apa itu istilah akuntansi syariah, yaitu ketika kuliah akuntansi syariah, dan ternyata menarik juga yah!". Sedangkan menurut Sri Wahyuni yaitu: "disaat baru pertama kali mempelajari mata kuliah akuntansi syariah, saya belum begitu memahami apa sebenarnya yang dimaksud dengan akuntansi syariah. Namun setelah kuliah, ternyata banyak perbedaan istilah-istilah yang dipakai di akuntansi syariah pada tataran praktik di lembaga jasa keuangan syariah (perbankan syariah), dengan yang ada di istilah akuntansi konvensional (perbankan konvensional)".

Berbagai ragam infromasi tersebut di atas, ternyata Yuliana Jasmin, juga menyatakan hal yang senada, sebagaimana yang diungkapkan oleh Yulia dan Muhammad Fadhilah pada penjelasan sebelumnya, yaitu, "sebenarnya materi yang saya telah saya peroleh waktu mengikuti mata kuliah Akuntansi Perbankan Syariah, hal itu sudah pernah saya peroleh ketika saya sekolah di SMK dahulu. Ketika masih kuliah dahulu, materi yang saya peroleh seperti mengulang-ulang kembali pelajaran perbankan yang di dalamnya terdapat materi perbankan syariah".

\section{Akuntansi Syariah pada Tataran Teori dan Praktik Perspektif Informan}

Setelah peneliti melakukan wawancara mengenai apakah mengenal Lembaga Jasa Keuangan Syariah (LJKS), pada kelima informan penelitian (Yulia, Muhammad Fadhillah, Halimah, Sri Wahyuni dan Yuliana Jasmin) menjawab hal yang sama yakni “ ya, saya mengetahui lembaga 
jasa keuangan syariah”. Setelah itu peneliti bertanya mengenai apa Anda tertarik untuk bekerja di salah satu Lembaga Jasa Keuangan Syariah tersebut dan apa mata kuliah Akuntansi Syariah yang telah kalian tempuh berperan dalam hal tersebut?. Berikut uraian jawaban atas pertanyaan peneliti, yaitu:

Yulia mengatakan "cita-cita saya sebenarnya adalah bekerja di bagian audit pemerintahan yaitu BPK. Tetapi kalau ditanya tertarik untuk bekerja di salah satu LJKS, sepertinya tidak, karena cita-cita saya di awal yaitu ingin bekerja di BPK dan menurut saya mata kuliah yang saya pelajari tidak terlalu berpengaruh pada cita-cita saya untuk bekerja nantinya. Tetapi jika nanti ada lowongan kerja di salah satu LJKS tersebut, yah tentunya saya akan manfaatkan lowongan kerja itu, tetapi terkadang dipikiran saya, apakah materi yang saya telah saya peroleh di bangku kuliah, akan sama dengan kenyataan yang sebenarnya di dunia kerja. Karena terkadang saya mendengar cerita dari orang-orang yang telah bekerja, kalau teori tidak sama dengan kenyataannya. Jadi saya inginkan setiap mata kuliah kompetendi di bidang akuntansi, itu ada praktikumnya dan kalau perlu dilakukan kunjungan industri ke kantor-kantor atau industri perusahaan untuk melihat secara langsung tentang bagaimana yang dimaksud dengan dunia kerja. Misalnya saja mata kuliah Audit, itu praktikumnya sudah ada, tetapi saya mengiginkan ada kunjungan ke kantor auditor, untuk melihat secara langsung tentang proses mengaudit yang sebenarnya. Nah kalau mata kuliah Akuntansi Perbankan Syariah, hanya mentahui dari sisi teorinya saja, namun tidak mengetahui praktiknya. Harapan saya, agar sebaiknya ada praktikumnya, supaya bisa lebih mengetahui secara aplikatif materi yang ada di mata kuliah Akuntansi Syariah tersebut".

Sedangkan jawaban Muhammad Fadhillah "Saya memang sangat tertarik dengan hal yang berhubungan dengan akuntansi syariah maupun perekonomian syariah. Berdasarkan informasi yang saya peroleh setelah membaca beberapa literatur tentang Akuntansi syariah, menyebutkan bahwa dewasa ini lembaga atau institusi dari jasa industri keuangan berbasis syariah, saat ini telah mengalami perkembangan yang pesat, dan bahkan dapat bertahan dalam kondisi ekonomi yang tidak menentu, seperti sekarang ini dan akan sangat membanggakan bagi diri saya, jika bisa kerja di salah satu lembaga jasa keuangan syariah. Saya tertarik untuk berkarir di lembaga jasa keuangan syariah, bukan karena mata kuliah akuntansi perbankan syariah yang telah saya peroleh, akan tetapi karena keinginan saya dari lubuk hati yang paling dalam. Saya tetap optimis dan berkomitmen untuk terus berusaha agar bisa bekerja di lembaga jasa keuangan syariah. Sebenarnya waktu kuliah akuntansi perbankan syariah, saya sangat mengharapkan ada praktikumnya atau setidaknya ada program study banding untuk berkunjung ke bank syariah",

Halimah menyatakan "walaupun sudah lulus mata kuliah akuntansi syariah saya sepertinya tidak berminat untuk bekerja di lembaga jasa keuangan syariah, karna saya bercita-cita untuk bekerja di sektor swasta, karena menurut saya, bekerja di sektor swasta akan lebih menjanjikan dari sisi penghasilan (income). Di samping itu, saya juga mengiginkan adanya praktikum di setiap mata kuliah akuntansi. Misalnya mata kuliah akuntansi syariah, itu praktikumnya tidak ada, jadi waktu kuliah dulu, saya sulit untuk membayangkan bagaimana sistem kinerja operasional di jasa lembaga keuangan syariah tersebut. Begitu pula dengan mata kuliah kompetensi di bidang akuntansi yang lain, misalnya akuntansi pemerintahan. Selama ini kita mengetahui tata cara menjurnal sesuai dengan teori yang ada, tetapi kurang puas rasanya jika tidak banyak latihan kasus seperti yang terdapat pada mata kuliah akuntansi pengantar, yang disertai praktikumnya, sehingga pemahaman akan teorinya, itu menjadi lebih baik."

Menurut Sri Wahyuni "setelah lulus mata kuliah akuntansi syariah, saya tertarik untuk bekerja di lembaga jasa keuangan syariah, dalam hal ini, tidak mesti harus di perbankan syariah, lembaga keuangan syariah apapun namanya, insya Allah saya besedia. Misalkan di bank syariah, pegadaian syariah, asuransi syariah, atau koperasi syariah yang penting berkaitan dengan sistem syariah. Di samping itu, saya mengiginkan materi yang ada pada mata kuliah Akuntansi syariah, juga dijelaskan secara mendetail mengenai maksud dari angkaangka di dalam laporan keuangan, karena selama kuliah, yang dijelaskan hanya seputar teorinya saja, dan bentuk jurnal-jurnal dari setiap transaksi, tetapi tidak pernah diberikan kasus yang benar-benar ada. $Y a$, minimal cara baca laporan keuangan perusahaan bank syariah. Bahkan saya sempat malu kepada orang tua saya, ketika di suruh menjelaskan angka-angka yang terdapat di dalam laporan keuangan perusahaan yang dimuat di Koran nasional, tetapi saya tidak bisa jelaskan. Hal ini disebabkan ketika kuliah dahulu, tidak pernah diajarkan cara membaca laporan keuangan, kami hanya mampu untuk menyusun laporan keuangan, tetapi tidak diajarkan cara membaca laporan keuangan yang telah disajikan. Berdasarkan pada realitas tersebut di atas, perlu diadakan pelatihan atau semacamnya yang diberikan kepada mahasiswa akuntansi, agar mereka mampu untuk membaca laporan keuangan, dan menjelaskan makna dibalik angka-angka tersebut”.

Hal senada diungkapkan oleh Yuliana Jasmin, yaitu sebenarnya saya juga tertarik untuk suatu saat nanti, bisa bekerja di salah satu lembaga jasa keuangan syariah. Intinya ketika saya bekerja 
nanti, itu sudah sesuai dengan bidang ilmu saya, yaitu akuntansi. Saya sangat berharap, ilmu yang saya peroleh dapat bermanfaat bagi diri saya sendiri, dan juga bermanfaat bagi orang banyak. Mata kuliah Akuntansi Syariah secara tidak langsung ikut mempengaruhi pandangan saya terhadap cita-cita saya nantinya. Di sisi lain, muncul keraguan terhadap ilmu yang saya telah peroleh di bangku kuliah. Keraguan ini disebabkan karena adanya pernyataan dari orang-orang disekitar saya, yang telah bekerja dan mengatakan bahwa, teori yang kamu pelajari tidak sama dengan kenyataan yang ada. Sehingga saya merasa ada yang kurang dengan ilmu saya yakni aplikasi yang kurang, misalnya saja tugas-tugas kuliah tidak relevan dengan kasus-kasus yang sebenarnya terjadi, saya mengiginkan setiap dosen yang mengampuh mata kuliah akuntansi, ketika menjelaskan teori, itu seharusnya disertai dengan contoh-contoh kasus yang tengah terjadi di lingkungan perusahaan. Misalnya saja mengenai mudharabah, kami mengetahui definisi mudharabah, tetapi aplikasi yang sebenarnya, itu seperti apa? Seharusnya pihak kampus memfasilitasi program kunjungan ke lembaga-lambaga yang memang banyak terkait dengan mata kuliah yang ada di jurusan akuntansi, atau dosennya yang lebih memberikan penjelasan dengan realitas yang ada atau pihak kampus yang memberikan pelatihan yang aplikatif bagi seluruh mahasiswa jurusan akuntansi".

Sehubungan dengan penjelasan tersebut di atas, berikut ini akan diuraikan mengenai alasan para informan penelitian untuk memilih di mana mereka akan bekerja, setelah lulus kuliah. Berikut jawaban informan penelitian, yaitu: Yulia menyatakan bahwa "saya memilih pekerjaan sesuai dengan cita-cita yang saya inginkan, yaitu, bekerja di kantor Badan Pemeriksa Keuangan (BPK) sebagai auditor pemerintah. Saya akan berusaha untuk mencapai cita-cita saya. Alasan saya milih ingin bekerja di BPK, karena sesuai dengan bidang ilmu akuntansi yang saya geluti selama ini, khususnya di bidang audit. Di samping itu, masa depan orang-orang yang bekerja di BPK itu cerah dan gajinya pun begitu fantastis besar, serta sangat membanggakan jika bisa bekerja di pemerintahan".

Muhammad Fadhilah menyatakan bahwa "saya nantinya menargetkan untuk bisa bekerja di salah satu lembaga jasa keuangan syariah, karena saya memang sangat berminat dengan perekonomian berbasis syariah. Saya yakin perekonomian syariah di Indonesia pasti akan berkembang pesat dan kuat. Mengenai gaji saya tidak mempermasalahkan besar atau kecilnya gaji tersebut, yang terpenting adalah tempat saya bekerja itu memiliki jenjang karir yang jelas, maksudnya ketika saya bekerja nanti, saya mengiginkan untuk mendapatkan kenaikan jenjang karir, sesuai dengan kinerja yang saya lakukan"

Hal berbeda sebagaimana diungkapkan oleh Halimah, yaitu bahwa "saya tidak tertarik bekerja di sektor syariah, tetapi jika ada lowongan pekerjaan di sektor tersebut, pastinya saya akan manfaatkan lowongan pekerjaan tersebut ketimbang nantinya tidak dapat pekerjaan. Mengenai motivasi kerja, hal itu akan muncul sendiri, ketika kita sudah bekerja, insya Allah akan memahami juga pekerjaan tersebut, karna tentunya saat masuk bekerja, itu biasanay ada pelatihan dari kantor/perusahaan tempat kita bekerja”.

Hal senada diungkapkan oleh Yuliana Jasmin, yaitu "saya tidak memilih-milih pekerjaan, yang penting sesuai dengan jurusan saya, dan ilmu saya dapat bermanfaat. Ya kalau lowongan pekerjaan di sektor lembaga jasa keuangan syariah yang ada, maka saya akan mencoba untuk mengajukan permohonan untuk lowongan pekerjaan tersebut. Pada prinsipnya semua jenis pekerjaan sama saja, yang penting itu sesuai dengan keilmuan yang saya miliki. Mengenai penghasilan (income), idealnya harus mengikuti aturan, atau standar penggajian yang berlaku, serta disesuaikan dengan beban pekerjaan yang dibebankan kepada saya"

Menurut Sri Wahyuni "selain tertarik bekerja di salah satu lembaga jasa keuangan syariah, orang tua pun menyarankan agar saya dapat bekerja di lembaga jasa keuangan berbasis syariah, mengenai penghasilan (income), saya tidak mempermasalahkan selama sistem penggajiannya, sesuai dengan standar yang berlaku umum”.

\section{Upaya Memaknai di Balik Pernyataan Infroman}

Menurut peneliti, makna di balik pernyataan Sri Wahyuni tersebut adalah, merupakan buah pepahaman dari akuntansi konvensional, yang menjadikan laba sebagai suatu keniscayaan di dalam laporan laba rugi (statement of income), pada laporan keuangan (financial report) yang disajikan setiap akhir periode akuntansi, telah mengantarkan wajah akuntansi konvensional yang di praktikkan dalan entitas bisnis, menjelma menjadi entitas bisnis yang mengedepankan nilai-nilai egoistik, individual, dan syarat dengan aroma materialistis, kapitalisme yang begitu mekanistik. Akibatnya, output yang dihasilkan berupa laporan keuangan, hanyalah menghasilkan bilangan atau angka-angka yang jauh dari nilai-nilai humanis, emansipatoris, transendental, dan teleologikal. Hal dapat dibuktikan, setiap individu atau mahasiswa jurusan akuntansi, mereka hanya mampu untuk menyusun laporan keuangan berdasarkan transaksi, namun mereka tidak mampu menjelaskan makna di balik angka-angka yang disajikan dalam laporan keuangan tersebut.

Makna di balik pernyataan Yulia adalah mencerminkan bahwa ia adalah seoarang yang 
cukup idealis dalam mempertahankan komitmen keilmuannya, namun di satu sisi, Yulia terjebak dalam perangkap ranah pemikiran kapitalisme, yaitu mengukur kebahagiaan masa depan dengan satuan nilai materi. Artinya Yulia hanya berpikir dengan bekerja di BPK, ia akan memperoleh status sosial yang tinggi, berupa pujian, sanjungan, baik di internal keluarga, teman sejawat, maupun di lingkungan masyarakat. Di sisi lain dengan bekerja di BPK, dia akan memiliki banyak materi untuk bisa untuk bisa memperoleh kesenangan dunia semata. Menurut peneliti, apa yang telah dikemukakan oleh Yulia, jauh dari pengamalan nilai-nilai Islam, dan hal ini akan merusak pola pikir orang lain untuk ikut-ikutan bergaya hidup hedonisme yang serba materialistis. Seharusnya tujuan orang bekerja adalah untuk ibadah, dalam rangka pengabdian/penghambaan kepada Allah SWT. Inilah makna dan hakekat dari nilai-nilai syariah yang sesungguhnya.

Makna di balik pernyataan Muhammad Fadhilah yaitu keinginan untuk bekerja di lembaga jasa keuangan syariah tanpa mempersoalkan berapa gaji atau penghasilan yang ia peroleh setiap bulannya, hal ini telah mencerminkan adanya keinginan yang kuat dari Muhammad Fadhilah untuk menjadikan pekerjaan sebagai ladang ibadah di sisi Allah SWT. Di samping itu, keinginan yang tulus dari Muhammad Fadhilah untuk mengabdikan ilmunya di lembaga jasa keuangan syariah, merupakan wujud dan komitmen yang kuat untuk menumbuh kembangkan lembaga-lembaga keuangan syariah di tanah air. Namun di sisi lain, Muhammad Fadhilah adalah sosok yang profesional, yaitu mengiginkan jenjang karirnya dihargai berdasarkan prestasi kinerjanya. Maknanya yaitu, Muhammad Fadhilah seorang muslim yang taat pada ajaran agamanya (hamblumminallah), di sisi lain ia juga seorang yang profesional, karena tidak mengharapkan jabatan, melainkan jabatan yang mendatanginya berdasarkan prestasi kinerjnya. Realitas ini sangat kontroversial dengan pernyataan Yulia sebelumnya.

Makna dari pernyataan Halimah dan Yuliana Jasmin tersebut, yaitu keduanya merupakan tipe pribadi yang memiliki beberapa kesamaan, yaitu menerima jenis pekerjaan apa adanya. Halimah dan Yuliana Jasmin bukanlah pribadi yang idealis, sebagaimana pribadi yang di miliki oleh Muhammad Fadhilah, dan juga bukan sosok pribadi yang materialistis sebagaimana tipe pribadi yang dimiliki oleh Yulia. Menurut peneliti, sikap dari Halimah dan Yuliana Jasmin yang tidak memilih-milih pekerjaan, merupakan ciri-ciri insan yang pandai bersyukur atas nikmat yang diperolehnya dari Allah SWT.

Dalam perspektif kehidupan masyarakat, Halimah dan Yuliana Jasmin merupakan pribadi yang mudah bergaul, dan menyesuaikan diri dimanapun mereka berada. Adapun kelemahan dari
Halimah dan Yuliana Jasmin ialah, kemungkinan mereka mudah terpengaruh oleh orang lain, sehingga dapat menyebabkan keduanya sulit untuk meraih jengang karir yang maksimal. Hal yang berbeda dari pribadi Yuliana Jasmin yaitu adanya anggapan bahwa semua pekerjaan adalah sama.

Menurut peneliti pernyataan ini menggambarkan bahwa pribadi Yuliana Jasmin lebih mengutamakan kebutuhan akan materi, ketimbang profesi. Suatu hal yang harus dipahami dalam dunia pfofesi apapun, bahwa seorang yang professional harus mampu dan berani untuk mempertaruhkan keahliannya, keprofesionalismenya kepada siapa saja yang membutuhkannya, baik di sektor publik (pemerintah), maupundi sektor privat (swasta). Mempertaruhkan keahlian yang kita miliki, bukan berarti menyombongkan diri, dan jangan dengan serta merta langsung dimaknai milih-milih pekerjaan, melainkan lebih kepada penghargaan atas segala jerih payah yang telah kita perjuangakan selama ini, melalui perjalanan waktu yang cukup panjang, dengan mempertaruhkan dan mengorbankan seluruh potensi dan sumber daya yang kita miliki melalui sebuah lembaga pendidikan tinggi, misalkan di Universitas, Politeknik maupun Sekolah Tinggi.

Allah SWT berfirman dalam Al-Qur'an surat AlMujadilah ayat 11 , yaitu:

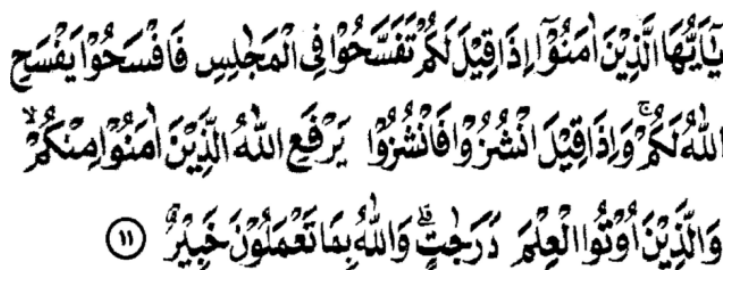

Hai orang-orang beriman apabila kamu dikatakan kepadamu: "Berlapang-lapanglah dalam majlis", maka lapangkanlah niscaya Allah akan memberi kelapangan untukmu, dan apabila dikatakan: "Berdirilah kamu", maka berdirilah, niscaya Allah akan meninggikan orang-orang yang beriman di antaramu dan orang-orang yang diberi ilmu pengetahuan beberapa derajat, dan Allah Maha mengetahui apa yang kamu kerjakan.

Makna dari pernyataan Sri Wahyuni tersebut adalah, Sri Wahyuni merupakan pribadi yang patuh, khususnya dalam menentukan pilihan bekerja, ia masih melibatkan kehendak orang tuanya. Artinnya, meskipun kemungkinan jenis pekerjaan yang diperolehnya, kurang sesuai dengan keinginan pribadinya, namun demi mengedepankan rasa berbakti kepada orang tua, maka pekerjaan yang telah diperolehnya tersebut, dapat dijalankan dengan baik dan penuh rasa tanggungjawab. Dalam dunia profesi dewasa ini, kemungkinan tipe pribadi dari Sri Wahyuni, dianggap sudah tidak relevan lagi dengan tuntutan zaman. Dunia profesi terkadang 
tidak mau berkompromi dengan keinginan pribadi, hal inilah yang kemungkinan dapat menyebabkan Sri Wahyuni tersisih dari percaturan dunia profesi dan bisnis yang begitu mengglobal.

\section{Matrik Hasil Penelitian}

Berdasarkan tahapan hasil penelitian tersebut di atas, maka untuk menghindari adanya kesalahan

persepsi dan penafsiran dari para pembaca, maka pada sesi akhir di hasil penelitian ini, penulis akan menyajikan matrik hasil penelitian. Dalam matrik hasil penelitian, terdiri atas: Pertama, Lima orang informan penelitian, kedua, indikator penelitian, dan yang ketiga yaitu hasil penelitian. Adapun matrik hasil penelitian yang dimaksud, nampak dalam tabel berikut ini:

Tabel 1.

Matrik Hasil Penelitian

\begin{tabular}{|c|c|c|c|}
\hline No & Informan Penelitian & Indikator Penelitian & Hasil Penelitian \\
\hline 1. & Sri Wahyuni & Akuntansi Syariah dan LJKS & $\begin{array}{l}\text { Masih terjebak dalam nilai-nilai } \\
\text { materi yang syarat dengan aroma } \\
\text { mekanistik }\end{array}$ \\
\hline 2. & Muhammad Fadhillah & Akuntansi Syariah dan LJKS & $\begin{array}{l}\text { Profesionalisme yang berjenjang } \\
\text { dalam berkarir di LJKS }\end{array}$ \\
\hline 3. & Halimah & Akuntansi Syariah dan LJKS & $\begin{array}{l}\text { Mengabaikan kesesuaian } \\
\text { dan Praktik dalam kinerja } \\
\text { operasional di LJKS. Masih } \\
\text { terjebak dalam lingkaran nilai } \\
\text { materi dalam memakna arti } \\
\text { sebuah penghasilan }\end{array}$ \\
\hline 4. & Yulia & Akuntansi Syariah dan LJKS & $\begin{array}{l}\text { Mengutamakan kesesuaian teori } \\
\text { dan praktik. Namun masih } \\
\text { terjebak dalam lingkaran nilai } \\
\text { materi dalam memaknai arti } \\
\text { sebuah penghasilan. }\end{array}$ \\
\hline 5. & Yuliana Jasmin & Akuntansi Syariah dan LJKS & $\begin{array}{l}\text { Mengabaikan kesesuaian } \\
\text { dan Praktik dalam kinerja } \\
\text { operasional di LJKS. Masih } \\
\text { terjebak dalam lingkaran nilai } \\
\text { materi dalam memaknai arti } \\
\text { sebuah penghasilan. }\end{array}$ \\
\hline
\end{tabular}

Sumber: Diolah, 2016

\section{Simpulan}

\section{Kesimpulan}

Berdasarkan hasil penelitian dalam matrik pada tabel 1 tersebut di atas, nampak bahwa, dari kelima informan penelitian tersebut, yaitu Sri Wahyuni terlepas dari kepentingan pribadi, dengan berupaya untuk memaknai angka-angka dalam laporan keuangan, dalam perspektif non materi. Berbeda dengan Muhammad Fadhillah, yang tidak mempersoalkan makna angka dibalik laporan keuangan, tetapi lebih mengutamakan kesesuaian antara teori dan praktik dalam barkarir di LJKS.

Halimah dan Yuliana Mengabaikan kesesuaian Teori dan Praktik dalam kinerja operasional di LJKS. Namun kedua informan penelitian ini, masih terjebak dalam lingkaran nilai materi dalam memakna arti sebuah penghasilan. Yaitu masih lebih mengutamakan prinsip yang penting bekerja, dan menghasilkan uang yang banyak, ketimbang mempertahankan idealisme dan profesinalisme. Sedangkah Yulia masih lebih mengutamakan kesesuaian teori dan praktik. Namun masih terjebak dalam lingkaran nilai materi dalam memaknai arti sebuah penghasilan. Secara keseluruhan disimpulkan bahwa mata kuliah akuntansi syariah yang ada di perguruan tinggi berperan bagi mahasisiwa akuntansi dalam pemilihan karir di LJKS.

\section{Implikasi Penelitian}

Perkembangan dari Lembaga Jasa Keuangan Syariah (LJKS) dari waktu ke waktu, telah mengalami kemajuan yang sangat pesat. Hal ini tidak terlepas dari peran utama Lembaga Pendidikan Tinggi, baik di tingkat Akademi, Sekolah Tinggi, Institut, dan Universitas, dalam menyediakan sumber daya manusia (human resources) yang terampil dan ahli dalam berbagai bidang dan disiplin ilmu. Sehubungan dengan hal tersebut, Perguruan Tinggi sebagai shareholders mempunyai posisi tawar yang sangat strategis dalam menyiapkan dan menghasilkan sumber daya manusia yang siap kerja, khususnya pada LJKS.

Agenda dalam penelitian ini yaitu, diharapkan semua Perguruan Tinggi pada tataran akademis dalam proses belajar mengajar (perkuliahan), agar lebih peka dalam memperhatikan 
kebutuhan dunia kerja, yaitu melalui kesesuaian antara teori dan praktik. Dalam hal ini, khususnya di jurusan akuntansi, melalui ketua jurusan, atau wakil; dekan bidang akademik, untuk melakukan penandatanganan kerjasama atau Memorandum of Understanding (MoU), dengan berbagai instansi yang terkait. Dengan demikian, para lulusan sarjana tidak merasa canggung tatkala mereka masuk ke dunia kerja nantinya.

\section{Keterbatan Penelitian}

Tingkat akurasi, dan pembahasan secara tuntas terhadap sebuah penelitian, merupakan suatu keniscayaan. Untuk menghasilkan penelitian yang baik dan memenuhi standar ilmiah, tentunya harus lebih memperhatikan luas cakupan penelitian yang diturunkan dalam rumusan masalah. Hal ini dimaksudkan agar peneliti dapat menyelesaikan proses penelitiannya secara efektif dan efisien.

Adapun yang menjadi batasan dalam penelitian ini yaitu, indikator penelitian hanya sebatas memaknai implikasi akuntansi syariah dalam tataran teori, dan dalam tataran praktik di Lembaga Jasa Keuangan Syariah (LJKS). Tujuan dari batasan penelitian yaitu untuk memberikan pemahaman kepada semua pihak bahwa, ruang lingkup dalam penelitian ini, hanya sebatas pada tataran pemaknaan atas semua infomasi yang disampaikan oleh informan penelitian seputar relevansi antara mata kuliah akuntansi syariah, dengan kinerja operasional di LJKS.

\section{Daftar Pustaka}

[1] Wiratama, W.J. dan K. Budiartha. 2015. Pengaruh Independensi, Pengalaman Kerja, Due Professional Care dan Akuntabilitas Terhadap Kualitas Audit. E-Jurnal Akuntansi Universitas Udayana 10 (1): 91-106.

[2] Singgih, M.E., dan I.R. Bawono. 2010. 2010. Pengaruh Independensi, Pengalaman, Due Professional Care, dan Akuntabilitas Terhadap Kualitas Audit (Studi pada Auditor di KAP "Big Four" di Indonesia). Simposium Nasional Akuntansi XIII. Purwokerto. Hal 1-24.

[3] Kharismatuti, N., dan P.B. Hadiprajito. 2012. Pengaruh Kompetensi dan Independensi Terhadap Kualitas Audit Dengan Etika Auditor Sebagai Variabel Moderasi. Jurnal Akuntansi 1 (1): 1-10.

[4] Christiawan, Y. Jogi. 2002. Kompetensi dan Independensi Akuntan Publik: Refleksi Hasil Penelitian Empiris. Jurnal Akuntansi dan Keuangan 4 (2): 79-92.

[5] Halim, A. 2014. Anggaran Waktu Audit dan Komitmen Profesional Sebagai Variabel Moderasi Pengaruh Kompetensi dan Independensi Auditor Terhadap Kualitas Audit. Simposium Nasional Akuntansi XVII 24-27 September 2014. Mataram, Lombok. Hal: 1-26.
[6]Arens, A.A., R.J. Elder and M.S. Beasley. 2010. Auditing and Assurance Service An Integrated Approach. International Edition, $13^{\text {rd }}$ Edition. Pearson Prentice-Hall, Inc. New Jersey-USA.

[7] De Angelo, L.E. 1981. Auditor Size and Auditor Quality. Journal of Accounting \& Economics 3. North-Holland Publishing Company. Hal 183-199

[8] IAPI. 2011. Standar Profesi Akuntan Publik. Salemba Empat. Jakarta-Indonesia.

[9] Arens, A.A., R.J. Elder and M.S. Beasley. 2008. Auditing dan Jasa Assurance Pendekatan Terintegrasi. Edisi Keduabelas. Erlangga. JakartaIndonesia.

[10] Alim, M.N., T. Hapsari dan L. Purwanti. 2007. Pengaruh Kompetensi dan Independensi Terhadap Kualitas Audit Dengan Etika Auditor Sebagai Variabel Moderasi. Simposium Nasional Akuntansi X 26-28 Juli 2007. Makasar. Hal 1-26.

[11] Saputra, A. Eka. 2012. Pengaruh Kompetensi dan Independensi Terhadap Kualitas Audit Dengan Etika Auditor Sebagai Variabel Moderasi (Studi Empiris pada Auditor di Kantor Akuntan Publik seJawa Tengah dan D.I Yogyakarta). JURAKSI 1 (2): 33-48.

[12] Samsi, N., A. Riduwan dan B. Suryono. 2013. Pengaruh Pengalaman Kerja, Independensi Dan Kompetensi Terhadap Kualitas Audit: Etika Auditor Sebagai Variabel Pemoderasi. Jurnal Ilmu dan Riset Akuntansi 1 (2): 207-226.

[13] Tjun, L.T., E.I. Marpaung dan S. Setiawan. 2012. Pengaruh Kompetensi dan Independensi Auditor Terhadap Kualitas Audit. Jurnal Akuntansi 4 (1): 33-56.

[14] Badjuri, A. 2011. Faktor-Faktor yang Berpengaruh Terhadap Kualitas Audit Auditor Independen Pada Kantor Akuntan Publik (KAP) di Jawa Tengah. Jurnal Dinamika Keuangan dan Perbankan 3 (2): 183-197.

[15] Messier, W.F., S.M. Glover, dan D.F. Prawitt. 2014. Jasa Audit dan Assurance Pendekatan Sistematis. Edisi Kedelapan Buku 1 \& 2. Salemba Empat. Jakarta-Indonesia.

[16] Mulyadi. 2002. Auditing. Edisi Keenam Buku 1. Salemba Empat. Jakarta-Indonesia

[17] Wardhani, P.K., dan B. Suryono. 2013. Pengaruh Akuntabilitas, Pengalaman, dan Due Professional Care Auditor Terhadap Kualitas Audit. Jurnal Ilmu dan Riset Akuntansi 2 (1): 1-15.

[18] Halim, A. 2008. Auditing. Edisi Keempat Jilid 1. Penerbit Sekolah Tinggi Ilmu Manajemen YKPN. Yogyakarta-Indonesia.

[19] Masrizal. 2010. Pengaruh Pengalaman dan Pengetahuan Audit Terhadap Pendeteksian Temuan Kerugian Daerah (Studi Pada Auditor Inspektorat Aceh). Jurnal Telaah dan Riset Akuntansi 3 (2): 173194.

[20] Adriyani, A., Andreas, dan Hardi. 2013. Pengaruh Keahlian, Independensi, Kecakapan Profesional, Tingkat Pendidikan Terhadap Kualitas 
Hasil Pemeriksaan Dengan Pengalaman Kerja Sebagai Variabel Moderating. Jurnal Akuntansi Keuangan dan Bisnis 6 (1): 1-15.

[21] Kell, G.W., W.C. Boynton dan R.E. Ziegler. 1986. Modern Auditing. Third Edition. John Wiley $\&$ Sons, Inc. New York-USA.

[22] Sukriah, A., dan B.I. Inapty. 2009. Pengaruh Pengalaman Kerja, Independensi, Objektifitas, Intergritas dan Kompetensi Terhadap Kualitas Hasil Pemeriksaan. Simposium Nasional Akuntansi XII 39 November 2009. Palembang. Hal: 1-38.

[23] Hidayat, W. 2010. Peran Faktor-Faktor Individual dan Pertimbangan Etis Terhadap Perilaku Auditor dalam Situasi Konflik Audit pada Lingkungan Inspektorat Sulawesi Tenggara. Jurnal Mitra Ekonomi dan Manajemen Bisnis 1 (2): 15-28. [24] Wilasita, I.A., E. Sujana, dan M.S. Lucy. 2014. Pengaruh Independensi, Due Professional Care, dan Kepatuhan Pada Kode Etik Terhadap Kualitas Hasil Pemeriksaan Audit (Studi Empiris Pada KAP Denpasar). Jurnal S1 Ak Universitas Pendidikan Ganesha 2 (1): 1-10.

[25] Febriansyah, E., M. Rasuli dan Hardi. 2014. Pengaruh Keahlian, Independensi, Kecermatan Profesional, Dengan Etika Sebagai Variabel Moderasi Terhadap Kualitas Auditor Pada Inspektorat Provinsi Bengkulu. Jurnal SOROT 8 (1): 1-14.

[26] Agustin, A. 2013. Pengaruh Pengalaman, Independensi, dan Due Professional Care Auditor Terhadap Kualitas Audit Laporan Keuangan Pemerintah (Studi Empiris pada BKP-RI Perwakilan Provinsi Riau. Jurnal Akuntansi 1 (1): 1-24.

[27] Nugrahaningsih, P. 2005. Analisis Perbedaan Perilaku Etis Auditor di KAP Dalam Etika Profesi (Studi Terhadap Peran Faktor-Faktor Individual: Locus Of Control, Lama Pengalaman Kerja,
Gender, dan Equity Sensitivity). Simposium Nasional Akuntansi VIII 15-16 September. Solo. Hal: 617-630

[28] Mujiyati. 2006. Pengaruh Partisipasi Pemakai Terhadap Kepuasan Dalam Pengembangan Sisitem Informasi Yang Dimoderasi Kompleksitas Tugas, Kompleksitas Sistem, Dan Pengaruh Pemakai. Laporan Hibah Penelitian PHK-A2. Jurusan Akuntansi Fakultas Ekonomi Universitas Muhammadiyah Surakarta. Tidak Dipublikasikan.

[29] Agusti, R dan N. P. Pertiwi. 2013. Pengaruh Kompetensi, Independensi dan Profesionalisme Terhadap Kualitas Audit (Studi Empiris Pada Kantor Akuntan Publik Se Sumatera). Jurnal Ekonomi 21 (3): 1-13.

[30] Primaraharjo, B. dan J. Handoko. 2011. Pengaruh Kode Etik Profesi Akuntan Publik Terhadap Kualitas Audit Auditor Independen di Surabaya. Jurnal Akuntansi Kontemporer 3 (1): 27 51.

[31] Futri, P.S. dan G. Juliarsa. 2012. Pengaruh Independensi, Profesionalisme, Tingkat Pendidikan, Etika Profesi, Pengalaman, dan Kepuasan Kerja Auditor Pada Kualitas Audit Kantor Akuntan Publik di Bali. Jurnal Akuntansi Universitas Udayana 2 (2): 444-461.

[32] Widyanto, A. 2012. Pengaruh Independensi, Due Professional Care, dan Akuntabilitas Terhadap Kualitas Audit Dengan Etika Profesi Sebagai Variabel Moderating (Studi Empiris pada Auditor Kantor Akuntan Publik di Wilayah Surakarta dan Yogyakarta). Skripsi. Fakultas Ekonomi dan Bisnis Universitas Muhammadiyah Surakarta. Surakarta. Tidak dipublikasikan 
Sutrisna dan Muchlis, 2016 